\title{
The incidence of abnormal spermatozoa in Armigeres subalbatus (Coquillett, 1898)
}

\author{
Yasumasa Tongu, ${ }^{*}$ Jim Shung LaI, ${ }^{*}$ Toshiki AjI, ${ }^{*}$ Setsuo Suguri, ${ }^{* *}$ \\ Ho Li Shing* and Seiiti Inatomi* \\ * Department of Parasitology, Okayama University Medical School, \\ 2-5-1 Shikata-cho, Okayama 700, Japan \\ ** Division of Medical Zoology, Department of Pathology, Kagawa Medical School, \\ Miki-cho, Kita-gun, Kagawa 761-07, Japan
}

(Received: December 12, 1981)

\begin{abstract}
The incidence of abnormal spermatozoa in the vesicles of each of 10 mosquitoes was examined by electron microscopy. Mosquitoes Armigeres subalbatus used in this study had been maintained in the laboratory for 160 generations after being collected in Kanagawa Prefecture. Normal spermatozoa had 1 flagellum and 2 mitochondria, but abnormal ones had unusual numbers of them. The counts of all normal and abnormal spermatozoa were taken from one side of the doublelumen of a cross-section. Abnormal spermatozoa were detected in the probability of $4.37 \%$, which was averaged from data on 10 seminal vesicles.
\end{abstract}

\section{INTRODUCTION}

Ultrastructural features of various organs in normal mosquitoes have been described by several electron microscopists, including the spermathecae in Aedes aegypti (Clements and Potter, 1967), the antennal sensilla of Aedes aegypti (McIver and Siemicki, 1979), the corpus cardiacum of Aedes sollicitans (Meola and Lea, 1972), the male accessory gland of Aedes triseniatus (Ramalingam and Craig, 1978), the malpighian tubule of Culex pipiens pallens, the salivary gland of Culex tritaeniorhynchus (Suguri et al., 1969, 1972), the spermatozoa in Culex pipiens pallens, the hind-gut of Aedes aegypti, the flight muscle of Culex pipiens pallens, and the male accessory gland of Culex pipiens pallens (Tongu et al., 1968, 1969, 1972a, 1972b).

* 頓宮廉正, 頼 俊雄, 安治敏樹, 何 黎星, 稲臣 成一：岡山大学医学部寄生虫学教室 (₹700 岡山 市鹿田町 2-5-1)

** 村主節雄: 香川医科大学病理学講座医動物学教室 (テ761-07 香川県木田郡三木町大字池戸1750-1)
Clements and Potter (1967), and Tongu et al. $(1968,1972 \mathrm{~b})$ have been studying the ultrastructure of normal spermatozoa in the spermathecae, the testis, and the accessory gland. To date, however, electron microscopists have not reported on the ultrastructure of abnormal spermatozoa appearing in normal seminal vesicles, or on the incidence of abnormal spermatozoa. The present study was undertaken to observe the ultrastructure and the incidence of abnormal spermatozoa in normal seminal vesicles of the mosquito Armigeres subalbatus maintained in the laboratory.

\section{Materials And Methods}

The mosquitoes used in this study were the species Armigeres subalbatus and had been maintained in the laboratory for 160 generations at $27^{\circ} \mathrm{C}$ and $80 \%$ humidity after being collected in Kanagawa Prefecture. Seminal vesicles were removed in Earles balanced salt solution (Ash and Schacher, 1971) from male adults 3 days after emergence, fixed in $3.5 \%$ phosphate-buffered glutaral- 
dehyde solution for $2 \mathrm{hr}$ in an ice box, then postfixed in buffered $1 \%$ osmium tetroxide for at least $1 \mathrm{hr}$ in an ice box. The vesicles were dehydrated in a graded series of ethanol, passed through $n$-butyl glycidyl ether, then embedded in Epon mixture. A cross-section containing many cross-sections of spermatozoa was obtained from the middle part of a seminal vesicle using a Porter-Blum ultramicrotome, and was stained with uranyl acetate and lead citrate. The number of whole normal and abnormal spermatozoa in one side of the double-lumen of a cross-section in each vesicle of 10 mosquitoes was counted out except for the head nucleus part, the tail end, and tangential sections which could not be certified as normal or abnormal with a Hitachi HS-8 electron microscope.

\section{Results}

Normal spermatozoa were composed of an electron-dense head nucleus (Fig. 1), a flagellum (Figs. 1, 3, 4) extending from the posterior nuclear groove to the posterior end of the spermatozoon, and 2 cord-like mitochondria (Figs. 1, 3, 4) running along a flagellum towards near the tail end. Abnormal spermatozoa (Figs. 1, 3, 4, arrows) differed from normal ones in the number of flagella or mitochondria. The number of abnormal spermatozoa observed in 10 vesicles is shown in Table 1 . Of all the spermatozoa, two in No. $V$ vesicles showed a maximum of 4 flagella each. The maximum number of mitochondria was 7 in a sperma-

Table 1 Numbers of abnormal spermatozoa in the vesicles of each of 10 normal mosquitoes (Counts were taken from one side of the double-lumen of a cross-section)

\begin{tabular}{|c|c|c|c|c|c|c|c|c|c|c|c|c|c|c|c|c|c|c|}
\hline \multirow{3}{*}{ SV } & \multicolumn{18}{|c|}{$F$} \\
\hline & \multicolumn{6}{|c|}{1} & \multicolumn{7}{|c|}{2} & \multicolumn{3}{|c|}{3} & \multicolumn{2}{|c|}{4} \\
\hline & $\mathbf{M}$ & 1 & 3 & 4 & 5 & 6 & 1 & 2 & 3 & 4 & 5 & 6 & 7 & 1 & 3 & 5 & 0 & 3 \\
\hline I & & 165 & 256 & 25 & 3 & & & 6 & 4 & 4 & & 1 & & & & & & \\
\hline II & & 131 & 106 & 9 & & & 2 & 31 & 19 & 10 & 1 & & & & & & & \\
\hline III & & 63 & 16 & 2 & & & 5 & 39 & 29 & 3 & & & & 2 & 3 & 1 & & \\
\hline IV & & 32 & 34 & 2 & & & & 5 & 2 & & & & & & & & & \\
\hline$\nabla$ & & 110 & 81 & 7 & 2 & 1 & 8 & 34 & 41 & 16 & & 2 & 1 & 1 & & & 1 & 1 \\
\hline VI & & 53 & 82 & 1 & & & & 5 & 4 & 3 & & & & & & & & \\
\hline VII & & 138 & 115 & 2 & & & & 6 & 6 & & & & & & & & & \\
\hline VIII & & 62 & 32 & 1 & & & & 17 & 9 & & & & & & & & & \\
\hline X & & 49 & 43 & & & & & 3 & 6 & & & & & & & & & \\
\hline$X$ & & 22 & 188 & 4 & & & 1 & 1 & 1 & 4 & & & & & & & & \\
\hline Total & & 825 & 953 & 53 & 5 & 1 & 16 & 147 & 121 & 40 & 1 & 3 & 1 & 3 & 3 & 1 & 1 & 1 \\
\hline
\end{tabular}

F: flagella, M: mitochondria, SV: seminal vesicles.

Fig. 1 Cross-sections of spermatozoa in a seminal vesicle containing abnormal spermatozoa with 2 flagella (arrows)

Scale: $1 \mu \mathrm{m}$.

Fig. 2 A middle part cross-section showing one side of the double-lumen of a seminal vesicle Scale: $10 \mu \mathrm{m}$.

Fig. 3 Cross-sections of spermatozoa in the seminal vesicle showing abnormal spermatozoa (arrows) with 3 mitochondrial cords

Scale: $1 \mu \mathrm{m}$.

Fig. 4 Cross-sections showing abnormal spermatozoa with 1 (arrow) and 4 mitochondrial cords (double arrow)

Scale: $1 \mu \mathrm{m}$. 

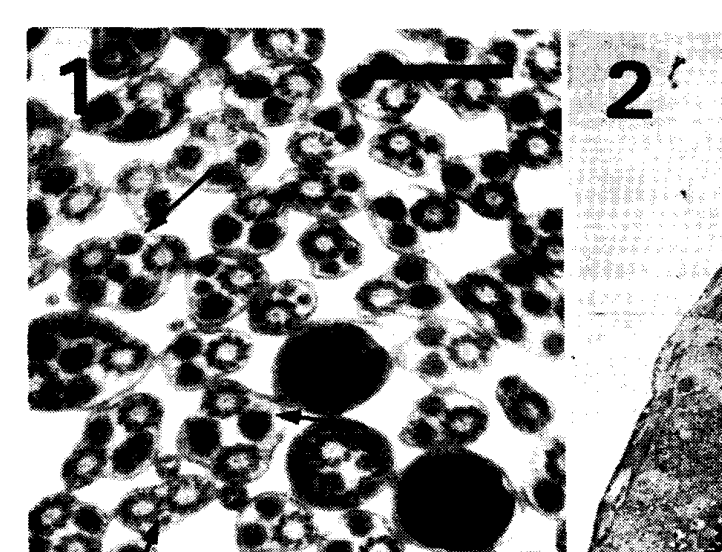

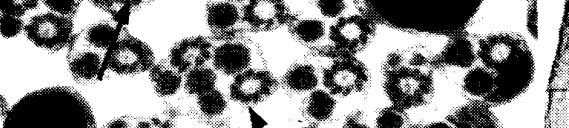

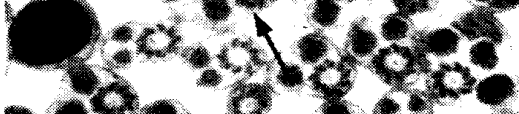

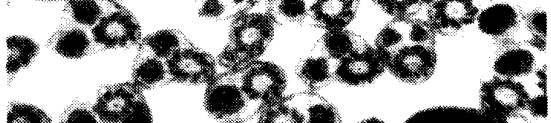

9.8 20 a

16 - 20 -

S.
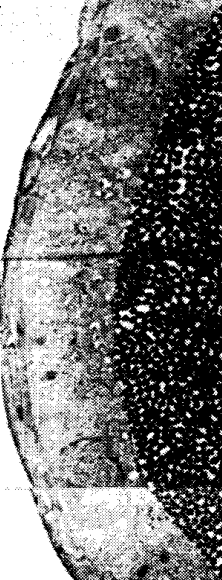

3)

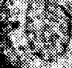

(3) $3+20$

$6,+2+2$

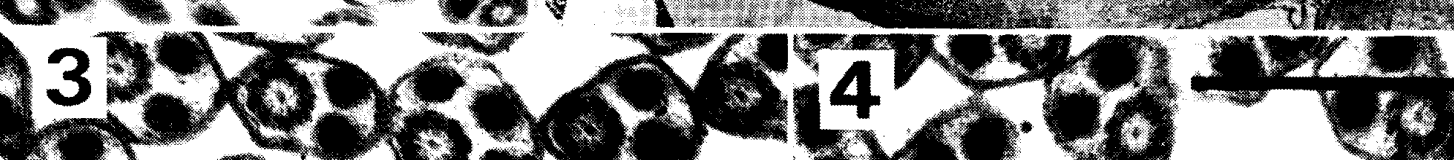

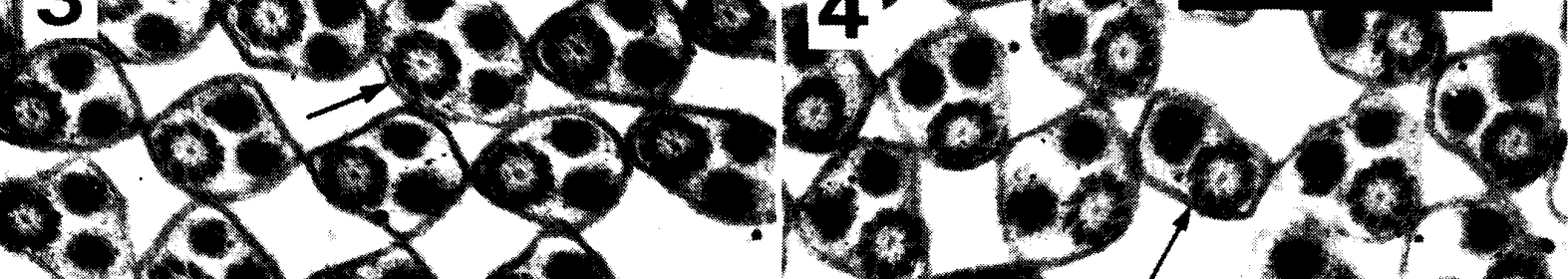

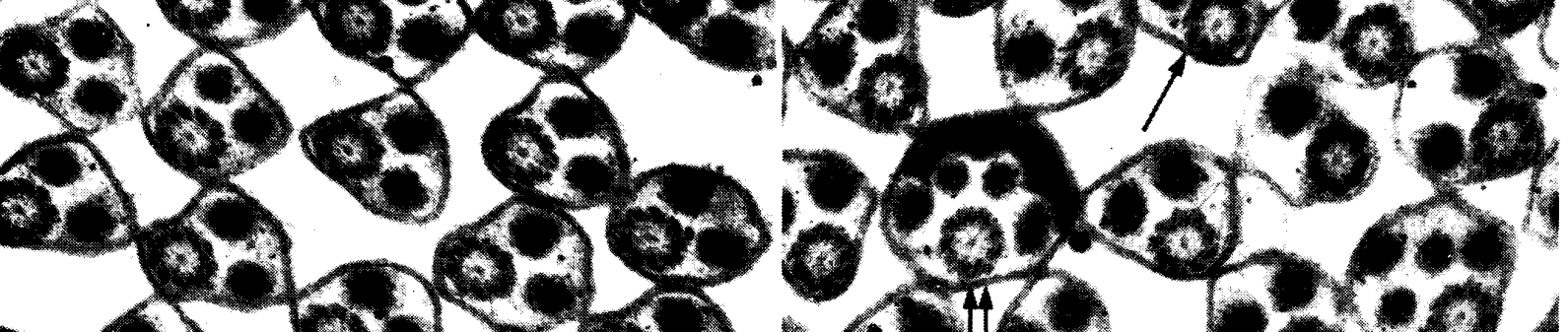

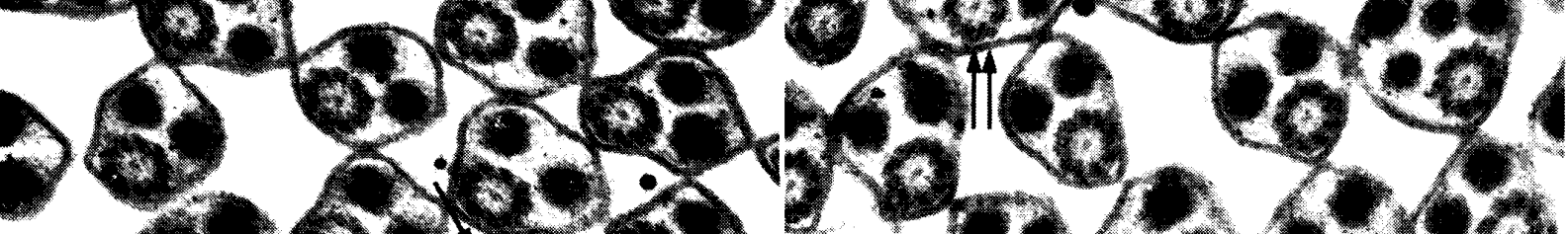

A.t.

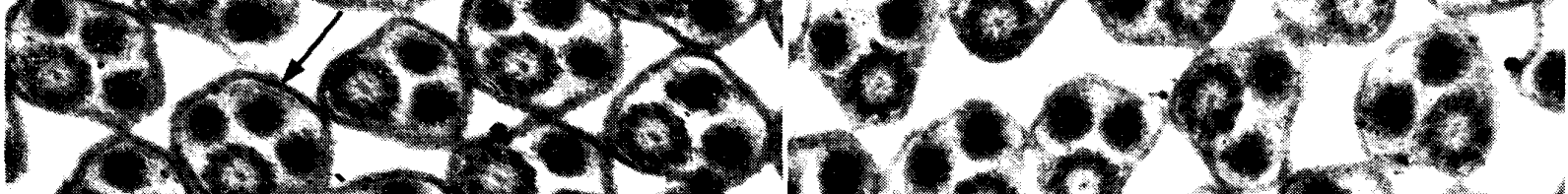

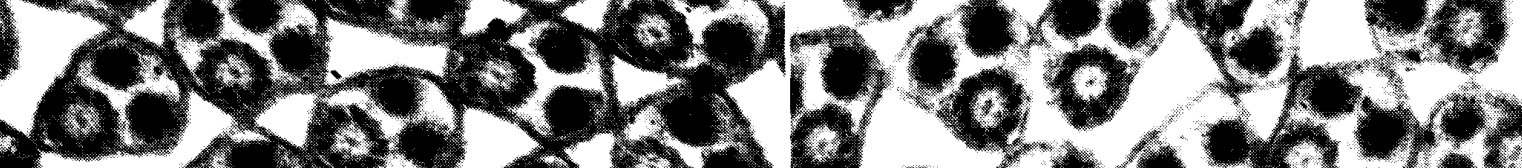

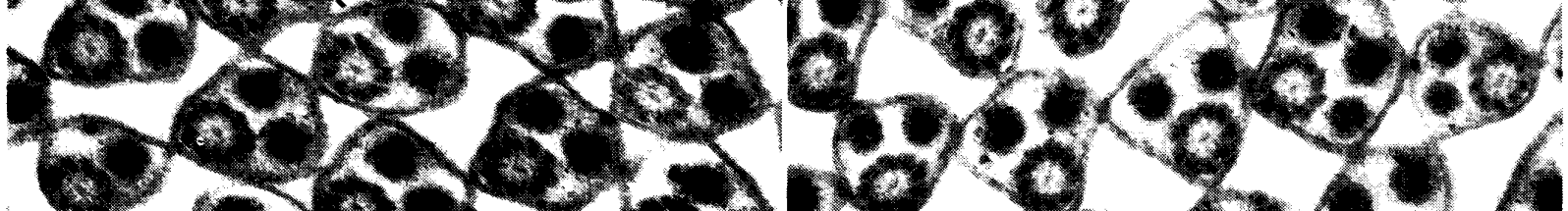

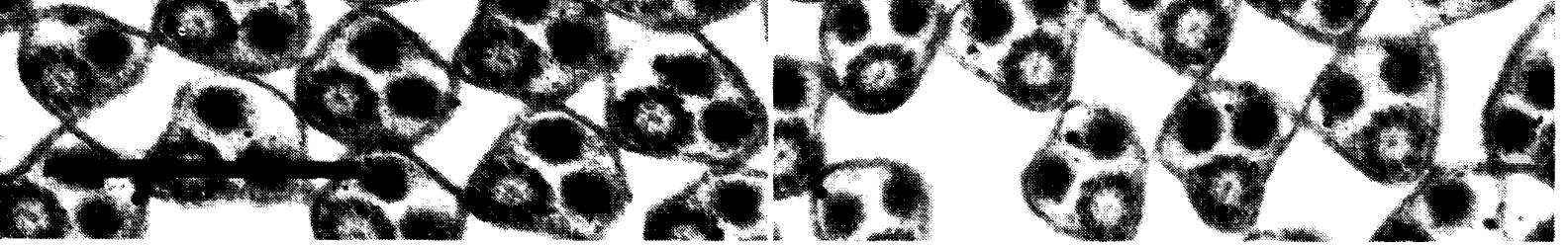

Figs. 1-4 
Table 2 Incidence of abnormal spermatozoa in the vesicles of each of 10 normal mosquitoes (Counts were taken from one side of the double-lumen of a cross-section)

\begin{tabular}{crrr}
\hline & \multicolumn{3}{c}{ Sperm } \\
\cline { 2 - 4 } SV & Normal & Abnormal & Total \\
\hline I & 8,777 & $464(5.02 \%)$ & 9,241 \\
II & 5,026 & $309(5.79 \%)$ & 5,335 \\
II & 4,733 & $163(3.32 \%)$ & 4,896 \\
IV & 2,732 & $75(2.67 \%)$ & 2,807 \\
V & 3,141 & $306(8.87 \%)$ & 3,447 \\
VI & 4,518 & $148(3.17 \%)$ & 4,666 \\
VII & 6,047 & $267(4.22 \%)$ & 6,314 \\
VIII & 5,936 & $121(1.99 \%)$ & 6,057 \\
IX & 3,769 & $101(2.60 \%)$ & 3,870 \\
X & 2,815 & $221(7.27 \%)$ & 3,036 \\
\hline Grand & 47,494 & $2,175(4.37 \%)$ & 49,669 \\
total & & & \\
\hline
\end{tabular}

SV: seminal vesicles.

tozoon of vesicle No. V. Most of the abnormal spermatozoa consisted of 1 flagellum and 1 or 3 mitochondria. The incidence of these abnormal spermatozoa from 10 normal mosquitoes is shown in Table 2. Among 10 vesicles, the highest incidence $(8.87 \%)$ of abnormal spermatozoa was in vesicle No. V, and the lowest $(1.99 \%)$ in vesicle No. VIII. The mean incidence estimated from 10 vesicles was $4.37 \%$.

\section{Discussion}

The ultrastructure of mosquito spermatozoa has been described by Clements and Potter (1967) and Tongu et al. (1968, 1972b). Tongu et al. (1968) gave a diagramatic drawing of a normal spermatozoon of Culex pipiens pallens. However, they have not referred to the presence of abnormal spermatozoa in normal mosquitoes. In the present observation, abnormal spermatozoa were present throughout the seminal vesicles of 10 normal Armigeres subalbatus. The incidence of abnormal spermatozoa ranged from 1.99 to $8.87 \%$, the average being $4.37 \%$, although the head nucleus part of spermatozoa, the tail end consisting of a flagellum only, and tangential sections were omitted from the count. The No. $\mathrm{V}$ vesicle had 4.5 times as many abnormal rates as the No. VIII. Increase in the number of mitochondria and flagella in a spermatozoon tended to be accompanied by a decrease in the number of spermatozoa having them. Other species of mosquitoes may have a different incidence of abnormal spermatozoa. Furthermore, the spermatogenesis of mosquitoes living in the natural habitat may be influenced by various factors including insecticides in the field. Such problems have yet to be clarified and largely depend upon future multilateral studies.

\section{ACKNOWLEDGMENT}

The authors wish to thank Mr. K. Itano for his help in preparing the photographs.

\section{REFERENGES}

Ash, L. R. and J. F. Schacher (1971): Early life cycle and larval morphogenesis of Wuchereria bancrofti in the jird, Meriones unguiculatus. J. Parasitol., 57: 1043-1051.

Clements, A. N. and S. A. Potter (1967): The fine structure of the spermathecae and their ducts in the mosquito Aedes aegypti. J. Insect Physiol., 13: 1825-1836.

McIver, S. and R. Siemicki (1979): Fine structure of antennal sensilla of male Aedes aegypti (L.). J. Insect Physiol., 25: 21-28.

Meola, S. M. and A. O. Lea (1972): The ultrastructure of the corpus cardiacum of Aedes sollicitans and the histology of the cerebral neurosecretory system of mosquitoes. Gen. Comp. Endocrinol., 18: 210-234.

Ramalingam, S. and G. B. Craig, Jr. (1978): Fine structure of the male accessory glands in Aedes triseriatus. J. Insect Physiol., 24: 251259.

Suguri, S., Y. Tongu, K. Itano, D. Sakumoto and S. Inatomi (1969): The ultrastructure of mosquitoes. 2. Malpighian tubule of Culex pipiens pallens. Jap. J. Sanit. Zool., 20: 1-6.

Suguri, S., Y. Tongu, D. Sakumoto, K. Itano and S. Inatomi (1972): The ultrastructure of mosquitoes. 5. Salivary gland of Culex tritaeniorhynchus. In: Research in Filariasis and Schistosomiasis, Vol. 2, pp.51-65, Univ. of Tokyo Press, Tokyo.

Tongu, Y., S. Suguri, K. Itano, D. Sakumoto and S. Inatomi (1968): The ultrastructure of mosquitoes. I. Spermatozoa in Culex pipiens pallens. Jap. J. Sanit. Zool., 19: 215-222. 
Tongu, Y., S. Suguri, D. Sakumoto, K. I tano and S. Inatomi (1969): The ultrastructure of mosquitoes. 3. Hindgut of Aedes aegypti. Jap. J. Sanit. Zool., 20: 168-176.

Tongu, Y., S. Suguri, D. Sakumoto, K. Itano and S. Inatomi (1972a): The ultrastructure of mosquitoes. 4. Flight muscle of Culex pipiens pallens. In: Research in Filariasis and Schistosomiasis, Vol. 2, pp.43-49, Univ. of Tokyo Press, Tokyo.

Tongu, Y., S. Suguri, D. Sakumoto, K. I tano and S. Inatomi (1972b): The ultrastructure of mosquitoes. 6. Male accessory gland of Culex pipiens pallens. Jap. J. Sanit. Zool., 23: 129139.

\author{
摘 要 \\ オオクロヤブカ Armigeres subalbatus \\ の奇型精子の発生率
}

オオクロヤブカは神奈川県で採集後, 160 代䍒験至 内で継代飼育したものを使用した. 羽化後 3 日目の雄 成虫より貯精囊を摘出し $3.5 \%$ のグルタールアルデヒ ドと $1 \%$ のオスミウムで二重固定した. 貯精䔩はエポ ンに包埋し中間部で 1 枚の横断切片を作って出てくる 2 個の管腔のうち, 片側の 1 個中にある精子の形態と 総数を透過型の電子顕微鏡で観察した. 正常な精子の 形態は星部に 1 本の鞭毛と 2 本のミトコンドリアを持 っているが，これらの数に增減のあるものを获型精子

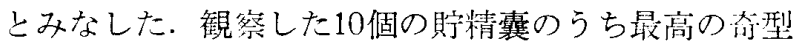
精子の発生率は $8.87 \%$ で最低は $1.99 \%$ ，平均では $4.37 \%$ の奇型率起示した. 